\title{
CONCENTRATION OF POTENTIALLY TOXIC ELEMENTS IN VARIOUS BERRIES GROWN IN ALLOTMENT GARDENS OF RIIGA CITY, LATVIA
}

\author{
Zane Vincēviča-Gaile ${ }^{\#}$ and Dāvis Varakājs \\ Faculty of Geography and Earth Sciences, University of Latvia, 1 Jelgavas Street, Rīga, LV-1004, LATVIA \\ \# Corresponding author, zane.vincevica@gmail.com
}

Communicated by Māris Kḷaviṇš

\begin{abstract}
Concentration of trace and major elements is an important indicator of nutritional value of food, also regarding cultivated food crops like fruits, berries, and vegetables. Concentration of elements differs regionally and is influenced by various factors. Nevertheless, some chemical elements (As, $\mathrm{Cd}, \mathrm{Hg}, \mathrm{Ni}, \mathrm{Pb}, \mathrm{Zn}$, etc.) are known as environmental pollutants and may affect the quality and safety of crops and food products. The aim of the study was to determine the concentration of potentially toxic elements like $\mathrm{Cd}, \mathrm{Cr}, \mathrm{Cu}, \mathrm{Fe}, \mathrm{Ni}, \mathrm{Pb}$, and $\mathrm{Zn}$ in samples of berries grown in allotment gardens of Riga city. Dried and homogenised samples of raspberries, strawberries, red currants, black currants, gooseberries, and cherries were mineralised in a solution of concentrated $\mathrm{HNO}_{3} / \mathrm{H}_{2} \mathrm{O}_{2}$ by heating on a thermoblock. Quantitative analysis of sample solutions was performed using atomic absorption spectroscopy. Potentially toxic elements were in concentrations as follows: $\mathrm{Fe}>\mathrm{Zn}>\mathrm{Cu}>\mathrm{Ni}>\mathrm{Pb}>\mathrm{Cr}>\mathrm{Cd}$. Mean concentrations of the elements of the major concern were: Ni $0.54 \mathrm{mg} / \mathrm{kg}, \mathrm{Pb} 0.20 \mathrm{mg} / \mathrm{kg}$, Cr $0.10 \mathrm{mg} / \mathrm{kg}$, and Cd $0.03 \mathrm{mg} / \mathrm{kg}$. Results indicated significant variability of element concentration among the species.
\end{abstract}

Key words: food composition, food contamination, heavy metals, quantitative analysis, urban gardening.

\section{INTRODUCTION}

Mineral compounds, particularly those containing trace and major elements, are among the basic essential nutrients in food. Metallic elements such as $\mathrm{Ca}, \mathrm{Fe}, \mathrm{K}, \mathrm{Mg}, \mathrm{Mn}, \mathrm{Na}, \mathrm{Zn}$, and $\mathrm{Cu}$ are unreplaceable for human health and their presence in daily diet is required at certain levels (Zarinš un Neimane, 2009; Kabata-Pendias, 2011). However, concentration of elements in food may vary due to several factors such as food commodity type, processing, and environmental conditions in crop and animal growing (Ekholm et al., 2007; Kabata-Pendias, 2011; Vincevica-Gaile, 2014). Regarding food crops, content of mineral compounds can be affected by applied agricultural practice, site specific conditions like soil mineral and water composition, weather conditions during the vegetation period, plant cultivar and species of plant, maturity of crops at harvesting and other site specific factors (Ekholm et al., 2007; Vincevica-Gaile, 2014). In the course of time, society has become accustomed to the fact that the conventional food market consists of various products derived from all over the world, and many consumers in everyday life do not pay great attention to the geographical origin or other specific impacts that can influence the chemical composition and quality of consum- able food products (Säumel et al., 2012; Warming et al., 2015).

Nowadays, in Europe and worldwide, urban or periurban allotment gardening has become more and more popular in society for recreation, as well as for domestic gardening and horticulture. For example, in big cities like Rio de Janeiro, New York, Berlin, and Copenhagen, space is allotted to citizens for creation of gardens for food crop cultivation for the needs of the community or individual family (Säumel et al., 2012; Reis et al., 2013; Rego, 2014; Chan et al., 2015; Warming et al., 2015).

Historical papers reveal that allotment gardening in Rìga started in the beginning of the $20^{\text {th }}$ century. In 1907, during the time when the territory of Latvia within the Russian Empire, creation of domestic gardens in urban areas was a novel concept, grounded on the idea that society needs an alternative for more useful spending time apart from vices like 'thinking socialistic' and excessive alcohol consumption (Livventāls un Sadovskis, 1932). After the First World War, unemployment, disrupted industry, poor traffic possibilities between the cities and rural districts, as well as a shortage of primary resources, inflation and hunger were the reasons to develop new ways of food gathering and time 
spending. Thus, the idea of allotment gardening was highly appreciated by the society. To meet the demands of the citizens of Rìga, many free territories, those which were destroyed during the war, were split into smaller plots and granted on lease by the city council. At that time, urban allotment gardening promoted decrease of food prices (Liventāls un Sadovskis, 1932). The popularity of urban allotment gardening in Rìga increased and decreased over time, and recently there has been a substantial reduction of total allotment area in the city, i.e., from 1600 ha in 1995 to 329 ha in 2011 (Duboks, 2012). However, urban allotment gardening in Rìga is still an essential tradition of the city. Currently, allotment gardens are located in several large territories in Rīga: Bolderāja (Daugavgrīva), Dārziṇi, Rumbula, and Lucavsala. Unfortunately, several of these areas are located on degraded land or in the vicinity of industrial areas and roads with heavy traffic, which may affect cultivated crop quality.

Quality of the urban environment is a problem that has been highlighted but often not taken into account (Säumel et al., 2012; Izquierdo et al., 2015). Increasing urbanisation has often constrained the formation of allotment (community or family) gardens or domestic farms at sites that have been polluted by industry in the past or that are under the influence of daily urban pollution, such as construction dust, industrial or traffic exhaust (Alexander et al., 2006; Wunderlich et al., 2011). However, in some cities it is common practice that allotment gardens are frequently created in areas near intensive traffic lines such as railways and highways, where soil and water quality is not appropriate for safe crop cultivation (Guitart et al., 2012). Air pollution may affect over-ground parts of plants by dust deposition, while soil and water quality may affect plants as a whole. Possible health hazards caused by consumption of contaminated food crops cultivated in industrial agriculture areas and available at the market have been recognised. However, vegetables and fruits grown in urban conditions mostly are consumed in the long-term by small groups of people (families or local communities) and, therefore, potential health impacts still are considered as less important. Anthropogenic activities can lead to an increased risk of allotment garden contamination, mainly by potentially toxic metals and metalloids such as $\mathrm{As}, \mathrm{Cd}, \mathrm{Cr}, \mathrm{Cu}, \mathrm{Hg}, \mathrm{Ni}, \mathrm{Pb}, \mathrm{Zn}$, etc., as well as by organic chemicals. Subsequent contamination in the food chain may affect animals or humans consuming vegetables and fruits that are grown in allotment gardens located in appropriate territories (Samsoe-Petersen et al., 2002; Goldhaber, 2003; Eggen et al., 2011; Wunderlich et al., 2011).

The aim of this study was to perform quantitative analysis of samples of various berries grown in allotment gardens of Riga city, the capital of Latvia. It should be noted that the available data on quality of food derived from allotment gardens in Rīga or other cities of Latvia are very limited (Vincevica-Gaile et al., 2011; Vincevica-Gaile, 2014). Thus, the current research is valuable in the fields of environmental and food sciences.

\section{MATERIALS AND METHODS}

Samples of berries from red currant Ribes rubrum $(\mathrm{n}=15)$, black currant Ribes nigrum $(\mathrm{n}=10)$, gooseberry Ribes uva-crispa $(\mathrm{n}=8)$, cherry Prunus sp. $(\mathrm{n}=8)$, strawberry Fragaria $x$ ananassa $(\mathrm{n}=19)$, and raspberry Rubus idaeus $(\mathrm{n}=11)$ plants grown in allotment gardens of Rìga were collected during the vegetation season in 2015. Samples were directly obtained at the allotment gardens located in different places of Riga (Fig. 1) within the limits of garden plots. However, the samples investigated in this study were not divided by allotment plot, but the territory of the gardens, to assess effect of the environmental conditions in the general neighbourhood. Samples consisted of about 150-200 g of every type of berry within a plot, and then mixed samples were made for the territory of the gardens. Only edible parts of berries were prepared for analysis. After collection, berries were cleaned and crushed using a porcelain knife (Kyocera) to avoid contamination with metals. Crushed samples were dried in a drying oven (Plus II Oven, Labassco) at temperature $80-105{ }^{\circ} \mathrm{C}$ for 20 hours and at temperature $105{ }^{\circ} \mathrm{C}$ for an additional 5-6 hours, if needed, depending on the consistency and moisture of the sample type. After drying, samples were homogenised in a porcelain mortar until consistence of powder was reached. Samples were stored in closed disposable plastic bags in a dry and dark place until analysis. Sample preparation and analytical procedures were conducted as described elsewhere (Samsoe-Petersen et al., 2002; Aras and Ataman, 2006; Ekholm et al., 2007; Vincevica-Gaile, 2014).

Carbohydrates, proteins and fats are the main matrix components of food samples that can influence quantitative trace element detection. Sample preparation (pre-treatment) can be carried out by several methods, such as dry ashing,

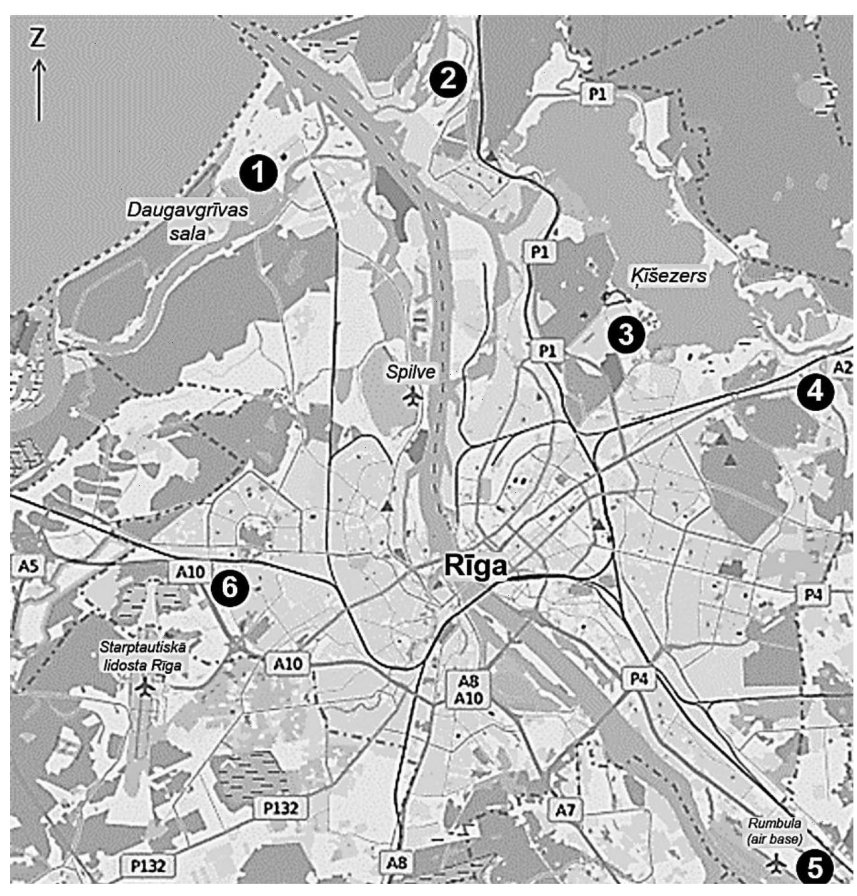

Fig. 1. Illustrative map of sampling sites of berries in allotment gardens of Rīga city: 1 - Daugavgrīva, 2 - Vecmīlgrāvis, 3 - Mežaparks, 4 - Jugla, 5 - Dārzini, 6 - Zolitūde. 
ACCURACY OF THE APPLIED ANALYTICAL METHOD

\begin{tabular}{|c|c|c|c|c|c|c|c|c|}
\hline \multirow[t]{3}{*}{ Element } & \multicolumn{3}{|c|}{$\begin{array}{l}\text { Analysis of certified reference material NCS ZC73017 } \\
\text { Apple powder }\end{array}$} & \multicolumn{5}{|c|}{ Quantitative performance of measurements using AAS } \\
\hline & \multirow{2}{*}{$\begin{array}{l}\text { range of certified value } \\
\text { of concentration, } \mathrm{mg} / \mathrm{kg}\end{array}$} & \multicolumn{2}{|c|}{ concentration determined by AAS } & \multirow{2}{*}{$\begin{array}{l}\text { detection limit, } \\
\mathrm{mg} / \mathrm{kg}\end{array}$} & \multirow{2}{*}{$\begin{array}{l}\text { quantitative } \\
\text { limit, } \mathrm{mg} / \mathrm{kg}\end{array}$} & \multirow{2}{*}{$\begin{array}{l}\text { uncertainty, } \\
\%\end{array}$} & \multirow{2}{*}{$\begin{array}{l}\text { detection } \\
\text { mode }\end{array}$} & \multirow{2}{*}{$\begin{array}{l}\text { spectral lines, } \\
\mathrm{nm}\end{array}$} \\
\hline & & $\begin{array}{l}\text { average concentration, } \\
\mathrm{mg} / \mathrm{kg}\end{array}$ & accuracy, $\%$ & & & & & \\
\hline $\mathrm{Cd}$ & $0.0046-0.0070$ & 0.0047 & 81.0 & 0.0035 & 0.0106 & 8.5 & GFAAS* & 228.8 \\
\hline $\mathrm{Cr}$ & $0.24-0.36$ & 0.26 & 86.7 & 0.03 & 0.11 & 7.7 & GFAAS & 357.9 \\
\hline $\mathrm{Cu}$ & $2.30-2.70$ & 2.41 & 96.4 & 0.27 & 0.89 & 5.1 & FAAS $* *$ & 324.8 \\
\hline $\mathrm{Fe}$ & $14.0-18.0$ & 15.3 & 95.6 & 0.27 & 0.90 & 8.4 & FAAS & 248.3 \\
\hline $\mathrm{Ni}$ & $0.09-0.19$ & 0.13 & 92.9 & 0.03 & 0.11 & 7.9 & GFAAS & 232.0 \\
\hline $\mathrm{Pb}$ & $0.052-0.116$ & 0.067 & 79.8 & 0.066 & 0.218 & 12.8 & GFAAS & 283.3 \\
\hline $\mathrm{Zn}$ & $1.70-2.50$ & 2.07 & 98.6 & 0.06 & 0.21 & 5.5 & FAAS & 213.9 \\
\hline
\end{tabular}

*GFAAS, graphite furnace atomic absorption spectroscopy; **FAA, flame atomic absorption spectroscopy

wet ashing, and wet digestion with heat, microwave or ultrasound treatment (Alvarez et al., 2003; Soceanu et al., 2007). The chosen sample preparation method of wet digestion of organic matter has been widely applied for samples of biological origin, including food (Ekholm et al., 2007; Soceanu et al., 2007). Preparation of samples was done as follows: a) $0.5000 \pm 0.0050 \mathrm{~g}$ of a dry sample were weighed on an analytical balance (ALJ 220-4, Kern) in a $100 \mathrm{~mL}$ glass beaker; b) $15 \mathrm{~mL}$ of concentrated $\mathrm{HNO}_{3}(65 \% \mathrm{w} / \mathrm{v}$, analytical grade, Scharlau) and $5 \mathrm{~mL}$ of concentrated $\mathrm{H}_{2} \mathrm{O}_{2}$ $(30 \% \mathrm{w} / \mathrm{v}$, analytical grade, Scharlau) were added; c) after holding overnight, sample solutions were digested by heating at temperature $160{ }^{\circ} \mathrm{C}$ on a heating block (Thermoblock, Biosan); d) after complete digestion and cooling, sample solutions were filled up to $15 \mathrm{~mL}$ with ultrapure deionised water $(<0.1 \mu \mathrm{S} / \mathrm{cm}, 18 \mathrm{M} \Omega / \mathrm{cm}$, Elix-3, Millipore) in polypropylene tubes; e) prior the analytical procedure, sample solutions were filtrated using disposable single use micropore syringe filters $(0.45 \mu \mathrm{m}$, SRC filter, ChmLab Group). All samples were prepared in triplicate. Accuracy of the applied method was approved by analysis of certified reference material, NCS ZC73017 Apple powder (Promochem), as well as blank samples in each batch of samples were prepared and analysed in the same manner as the investigated samples. Obtained results of reference material analysis showed precision within the permissible limits for selected elements (Table 1).

Sample solutions were analysed by atomic absorption spectroscopy method using a spectrometer AANALYST 200 (Perkin Elmer) to quantify concentration of seven elements $(\mathrm{Cd}, \mathrm{Cr}, \mathrm{Cu}, \mathrm{Fe}, \mathrm{Ni}, \mathrm{Pb}$, and $\mathrm{Zn})$. Characteristic parameters of quantitative performance of measurements using AAS are shown in Table 1. Absorption was measured in an air-acetylene flame and graphite furnace AAS. All obtained results of element concentration were expressed in $\mathrm{mg} / \mathrm{kg}$ DW (dry weight). Statistical analysis of data was performed using extended MS Excel data analysis tool QI Macros expressing results by box-whisker plots which show maximum, minimum and median values of certain data sets, as well as a range between $25^{\text {th }}$ and $75^{\text {th }}$ percentiles. Outlying values were identified and excluded if they were outside of selected range of percentiles. However, outlier values were taken into account in assessment of detected element concentration compliance with maximum permitted levels set by legislation.

\section{RESULTS}

Average concentrations of potentially toxic elements in samples of berries followed the following order: $\mathrm{Fe}>\mathrm{Zn}>$ $\mathrm{Cu}>\mathrm{Ni}>\mathrm{Pb}>\mathrm{Cr}>\mathrm{Cd}$. Figure 2 shows concentration ranges of $\mathrm{Fe}, \mathrm{Zn}$ and $\mathrm{Cu}$ in the analysed samples of berries. The highest median content of Fe was detected for strawberry $(39.0 \mathrm{mg} / \mathrm{kg})$, while for other berries the concentration was quite similar $(19.8-30.7 \mathrm{mg} / \mathrm{kg})$. Concentration of $\mathrm{Zn}$ was quite variable; the lowest values were observed for cherry (median $2.7 \mathrm{mg} / \mathrm{kg}$ ) and the highest for raspberry (median $19.7 \mathrm{mg} / \mathrm{kg}$ ). Concentration of $\mathrm{Cu}$ was the lowest (median $1.4 \mathrm{mg} / \mathrm{kg}$ ) also in cherry following by gooseberry (median $2.07 \mathrm{mg} / \mathrm{kg}$ ), while for the remaining samples the median varied from $2.8-4.1 \mathrm{mg} / \mathrm{kg}$.

Concentration of trace potentially toxic elements such as $\mathrm{Ni}$, $\mathrm{Pb}, \mathrm{Cr}$ and $\mathrm{Cd}$ varied more widely (Fig. 3). For Ni the highest median was detected in samples of strawberry $(0.65$ $\mathrm{mg} / \mathrm{kg}$ ), but the widest range was observed for black currant $(0.17-1.24 \mathrm{mg} / \mathrm{kg})$ and gooseberry $(0.18-0.99 \mathrm{mg} / \mathrm{kg})$. Taking into account average values of all analysed samples, the elements of the major concern in berries regarding high concentrations were as follows: $\mathrm{Ni} 0.54 \mathrm{mg} / \mathrm{kg}, \mathrm{Pb}$ $0.20 \mathrm{mg} / \mathrm{kg}, \mathrm{Cr} 0.10 \mathrm{mg} / \mathrm{kg}$, and $\mathrm{Cd} 0.03 \mathrm{mg} / \mathrm{kg}$. However, concentration of these elements differed among the berries. The widest range of values for $\mathrm{Pb}$ were detected in samples of red currant $(0.08-0.46 \mathrm{mg} / \mathrm{kg}$, median $0.30 \mathrm{mg} / \mathrm{kg}$ ), strawberry $(0.06-0.45 \mathrm{mg} / \mathrm{kg}$, median $0.18 \mathrm{mg} / \mathrm{kg})$ and raspberry $(0.14-0.44 \mathrm{mg} / \mathrm{kg}$, median $0.29 \mathrm{mg} / \mathrm{kg})$. For black currant, gooseberry and cherry, $\mathrm{Pb}$ concentration was lower and varied in much narrower range, e.g., $0.07-0.16 \mathrm{mg} / \mathrm{kg}$ (median $0.11 \mathrm{mg} / \mathrm{kg}$ ) for gooseberry. The widest range of $\mathrm{Cr}$ concentration was detected for black currant $(0.03-0.25 \mathrm{mg} / \mathrm{kg})$, while median values for all berries ex- 

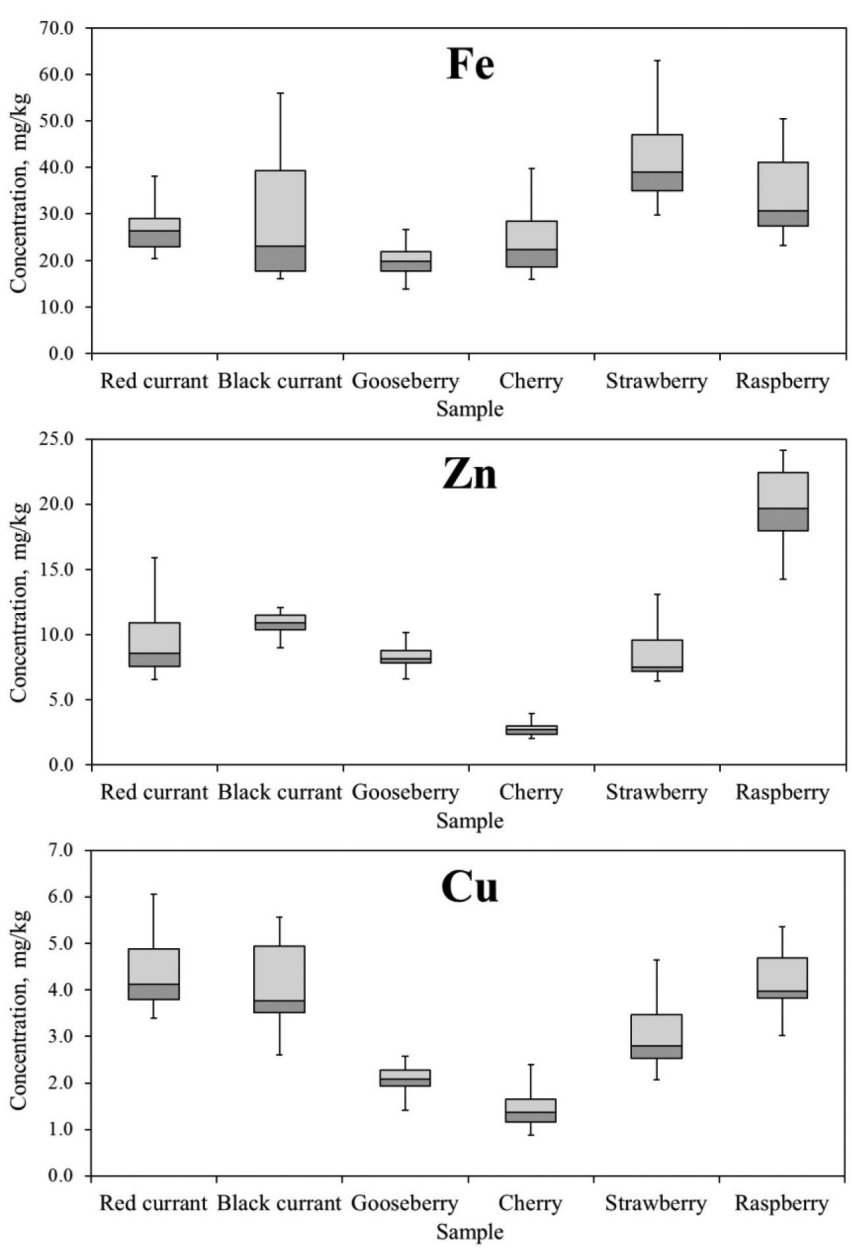

Fig. 2. Concentration of $\mathrm{Fe}, \mathrm{Zn}$ and $\mathrm{Cu}$ in berries from allotment gardens of Rìga.

cept gooseberry were quite similar (on average $0.09 \mathrm{mg} / \mathrm{kg}$ ). Concentration of $\mathrm{Cr}$ was the lowest in samples of gooseberry (median $0.03 \mathrm{mg} / \mathrm{kg}$ ). After excluding outliers, concentration of $\mathrm{Cd}$ in samples of black currant and cherry was below the detection limit $(0.004 \mathrm{mg} / \mathrm{kg})$, but in the remaining samples median concentration of $\mathrm{Cd}$ was from $0.02 \mathrm{mg} / \mathrm{kg}$ in raspberry to $0.03 \mathrm{mg} / \mathrm{kg}$ in red currant, gooseberry and strawberry. The highest values of $\mathrm{Cd}$ were observed for samples of strawberry $(0.12 \mathrm{mg} / \mathrm{kg})$, as well as for raspberry and red currant $(0.07 \mathrm{mg} / \mathrm{kg})$.

\section{DISCUSSION}

Element concentration of berries can reveal their nutritional value, as well as possible contamination in case of potentially toxic concentrations of elements. Thus, these values can be used for nutrient intake calculation and consumer risk assessment (Izquierdo et al., 2015; Warming et al., 2015). However, information on element content in berries grown for self-consumption is not widely represented in available scientific literature, and is especially poor is information for the Baltic States. More data can be found on research of element composition of vegetables than berries (e.g., Samsoe-Petersen et al., 2002; Säumel et al., 2012; Warming et al., 2015). A well organised food and nutrient
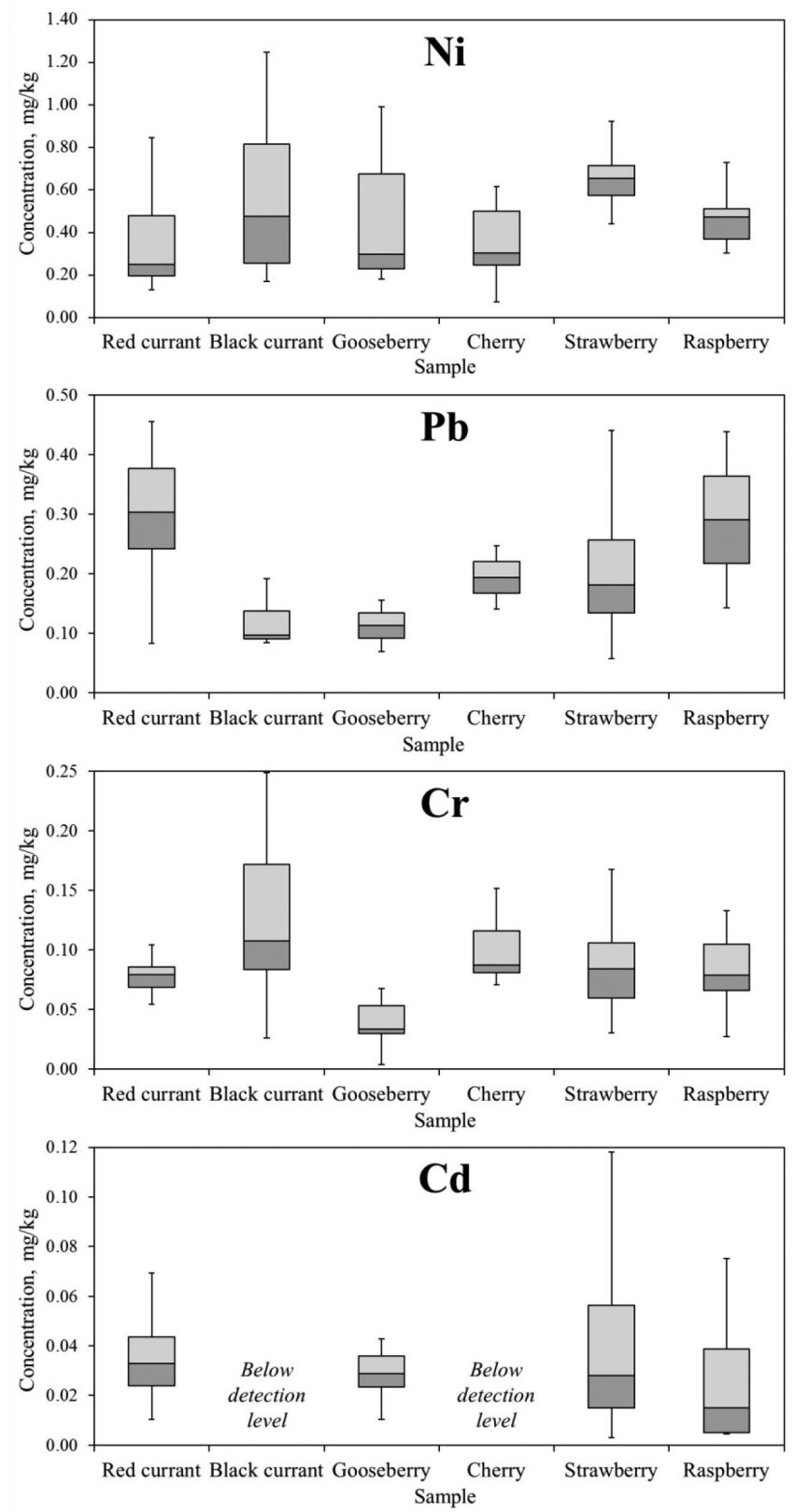

Fig. 3. Concentration of $\mathrm{Ni}, \mathrm{Pb}, \mathrm{Cr}$, and $\mathrm{Cd}$ in berries from allotment gardens of Rīga.

data base has been established by the United States Department of Agriculture Agricultural Research Service (Anonymous, 2016); it provides information on selected mineral nutrients $(\mathrm{Ca}, \mathrm{Fe}, \mathrm{Mg}, \mathrm{K}, \mathrm{Na}, \mathrm{Zn}, \mathrm{Cu}, \mathrm{Mn}, \mathrm{Se})$ in various foods, including raw or processed berries. Information on concentration of $\mathrm{Fe}, \mathrm{Zn}$ and $\mathrm{Cu}$ in berries according to the USDA NND (Anonymous, 2016) is recalculated to $\mathrm{mg} / \mathrm{kg}$ DW and summarised in Table 2. Data comparison revealed that concentration of $\mathrm{Fe}$ in red currants and black currants determined in the current research was significantly lower than values provided by the USDA NND, but for other berries the values are comparable to upper maximum. Also, for the elements $\mathrm{Zn}$ and $\mathrm{Cu}$, concentrations from the data base mostly correspond to the upper maximum determined for berries from Rīga. It should be noted that berries from allotment gardens might not be of the highest nutritional quality, which might explain the observed difference. 
CONCENTRATION OF FE, ZN AND CU IN RAW BERRIES ACCORDING TO THE USDA NATIONAL NUTRIENT DATABASE (ANONYMOUS, 2016), RECALCULATED TO MG/KG DW

\begin{tabular}{l|cccc|c}
\hline \multirow{2}{*}{ Species of berries } & \multicolumn{3}{|c|}{ Concentration of element, $\mathrm{mg} / \mathrm{kg}$} & Water content, \\
\cline { 2 - 4 } & $\mathrm{Fe}$ & $\mathrm{Zn}$ & $\mathrm{Cu}$ & 83.95 \\
\hline Red currant & 62.31 & 14.33 & 6.67 & 81.96 \\
Black currant & 85.37 & 14.97 & 4.77 & 87.87 \\
Gooseberry & 25.56 & 9.89 & 5.77 & 86.13 \\
Cherry, sour & 21.63 & 7.21 & 7.50 & 82.25 \\
Cherry, sweet & 20.28 & 3.94 & 3.38 & 90.95 \\
Strawberry & 45.30 & 15.47 & 5.30 & 85.75 \\
Raspberry & 48.42 & 29.47 & 6.32 &
\end{tabular}

Other studies have shown comparable values of element concentrations in berries, have indicating the range of influencing factors that can affect element concentration in samples. For example, a study done by S. Cosmulescu and colleagues (2015) compared element concentration among various cultivars of red currants and black currants. In that study, levels of Fe ranged from 10.9-24.7 mg/kg WW (wet weight) and $\mathrm{Cu} 0.9-1.7 \mathrm{mg} / \mathrm{kg} \mathrm{WW}$ in black currants. These values recalculated to dry weight are close to the determined element concentrations in the current study. Thus, berries from allotment gardens in Rīga do not have extreme levels of the studied metallic elements, despite the fact the gardens were located in possibly contaminated areas.

The list of top ten chemicals of major public concern, announced by the World Health Organisation (WHO), includes also several metallic elements $\mathrm{Cd}, \mathrm{Hg}, \mathrm{Pb}$ and a metalloid As, which are toxic already at low concentrations (Anonymous, 2010). Moreover, $\mathrm{Pb}$ can be accumulated in tissues of a living organisms (plants, animals and humans) and leading to wide and long-term contamination in the food chain (Goldhaber, 2003; Kabata-Pendias, 2011). Therefore, legislative limits for the elements of concern must be implemented at the national level. Within the European legislation, the maximum permitted levels in fruits and berries have been set only for some metallic element; the maximum permitted $\mathrm{Pb}$ concentration in berries and small fruits is $0.20 \mathrm{mg} / \mathrm{kg} \mathrm{WW}$ and the maximum permitted $\mathrm{Cd}$ concentration in fruits and vegetables is $0.05 \mathrm{mg} / \mathrm{kg}$ WW (Anonymous, 2006). Recalculation of data in the current study to wet weight showed that the maximum permitted level of $\mathrm{Pb}$ was not exceeded for all samples, even taking into account the detected maximum upper levels of concentration. However, some outlier values showed that in some specific cases contamination risk is present. Recalculation of $\mathrm{Cd}$ concentration from dry weight to wet weight suggested that concern can be given to strawberries, i.e., in some cases the maximum permitted level of $\mathrm{Cd}$ can be exceeded, thus warranting alert for consumer safety.

Presence of potentially toxic trace elements in berries indicated influence of environmental pollution taken up by the crops from air, soil and water. Air pollution may affect above-ground parts of plants by dust deposition, while soil and water quality may affect plants as a whole. However, this should be confirmed by wider and detailed study consisting of a greater number of analysed samples.

\section{CONCLUSIONS}

Quantitative analysis of potentially toxic elements in berries grown in allotment gardens of Rìga city showed differences of element concentration variation among the fruit species. Concentration of several metallic elements can indicate the nutritional value of berries. The range of trace elements, especially, if they are potential environmental pollutants, can provide information on the impact of environmental conditions on chemical composition of food crops. The results of the study showed that berries grown in the allotment gardens of Rìga contained potential environmental pollutants, among which $\mathrm{Pb}$ and $\mathrm{Cd}$ are elements of the major concern, especially taking into account the fact that concentration of these elements in some samples exceeded maximum permitted concentration levels in berries set by EU legislation. Such studies are important for understanding the impact of the surrounding environment on food composition regionally, which is important knowledge for local inhabitants, as for overall assessment of food safety.

\section{ACKNOWLEDGEMENTS}

This study was supported by the University of Latvia within the base funding for scientific research.

\section{REFERENCES}

Alexander, P. D., Alloway, B. J., Dourado, A. M. (2006). Genotypic variations in the accumulation of $\mathrm{Cd}, \mathrm{Cu}, \mathrm{Pb}$ and $\mathrm{Zn}$ exhibited by six commonly grown vegetables. Environ. Pollut., 144 (3), 736-745.

Alvarez, J., Marco, L. M., Arroyo, J., Greaves, E. D., Rivas, R. (2003). Determination of calcium, potassium, manganese, iron, copper and zinc levels in representative samples of two onion cultivars using total reflection X-ray fluorescence and ultrasound extraction procedure. Spectrochim. Acta B, $\mathbf{5 8}$ (12), 2183-2189.

Anonymous (2006). Setting maximum levels for certain contaminants in foodstuffs. EC Regulation 1881. Available from:

http://eur-1ex.europa.eu/legal-content/en/ALL/? uri= CELEX\%3A32006R1881 (accessed 3 October 2016).

Anonymous (2010). Action is needed on chemicals of major public health concern. WHO. Available from:

http://www.who.int/ipcs/features/10chemicals_en.pdf (accessed 3 October 2016).

Anonymous (2016). United States Department of Agriculture Agricultural Research Service National Nutrient Database for Standard Reference Release 28. Available from: https://ndb.nal.usda.gov/ndb/search/list (accessed 3 October 2016).

Aras, N. K., Ataman, O. Y. (2006). Trace Element Analysis of Food and Diet. RSC Publishing, Cambridge. 344 pp.

Chan, J., DuBois, B., Tidballd, K. G. (2015). Refuges of local resilience: Community gardens in post-Sandy New York City. Urban For. Urban Gree., 14 (3), 625-635.

Cosmulescu, S., Trandafir, I., Nour, V. (2015). Mineral composition of fruit in black and red currant. South Western J. Hortic., Biol. Environ., 6 (1), 43-51. 
Duboks, J. (2012). Dārzi un dārzkopība Rīgā: pilsētas zemes politikas un zaḷo teritoriju attīstības iespējas [Gardens and Gardening in Riga: Development Opportunities of City Land Politics and Green Territories]. Bachelor Thesis. University of Latvia, Riga, Latvia (in Latvian). 113 lpp.

Eggen, T., Moder, M., Arukwe, A. (2011). Emerging contaminants in consumer products: Environmental fate and transfer to human foodchain. In: Popov, V., Brebbia, C. A. (eds.). Food and Environment. WIT Press, Southampton, pp. 89-94.

Ekholm, P., Reinivuo, H., Mattila, P., Pakkala, H., Koponen, J., Happonen, A., Hellström, J., Ovaskainen, M.-L. (2007). Changes in the mineral and trace element contents of cereals, fruits and vegetables in Finland. J. Food Comp. Anal., 20 (6), 487-495.

Goldhaber, S. B. (2003). Trace element risk assessment: Essentiality vs. toxicity. Regul. Toxicol. Pharm., 38 (2), 232-242.

Guitart, D., Pickering, C., Byrne, J. (2012). Past results and future directions in urban community gardens research. Urban For. Urban Gree., 4 (11), 364-373.

Izquierdo, M., De Miguel, E., Ortega, M. F., Mingot, O. (2015). Bioaccessibility of metals and human health risk assessment in community urban gardens. Chemosphere, 135, 312-318.

Kabata-Pendias, A. (2011). Trace Elements in Soils and Plants. $4^{\text {th }}$ ed. CRC Press, Boca Raton. 505 pp.

Līventāls, T., Sadovskis, V. (red.) (1932). Rīga kā Latvijas galvaspilsēta [Rīga as a Capital City of Latvia]. Rīgas pilsētas valdes izdevums, Rīga. 638 lpp. (in Latvian).

Rego, L. F. G. (2014). Urban vegetable production for sustainability: The Riortas Project in the city of Rio de Janeiro, Brazil. Habitat Int., 44, $510-516$.
Reis, A. P., Patinha, C., Wragg, J., Dias, A. C., Cave, M., Sousa, A. J., Batista, M. J., Prazzeres, C., Costa, C., Ferreira da Silva, E., Rocha, F. (2013). Urban geochemistry of lead in gardens, playgrounds and schoolyards of Lisbon, Portugal: Assessing exposure and risk to human health. Appl. Geochem., 44, 45-53.

Samsoe-Petersen, L., Larsen, E. H., Larsen, P. B., Bruun, P. (2002). Uptake of trace elements and PAHs by fruit and vegetables from contaminated soils. Environ. Sci. Technol., 36 (14), 3057-3063.

Säumel, I., Kotsyuk, I., Hölscher, M., Lenkereit, C., Weber, F., Kowarik, I. (2012). How healthy is urban horticulture in high traffic areas? Trace metal concentrations in vegetable crops from plantings within inner city neighbourhoods in Berlin, Germany. Environ. Pollut., 165, 124-132.

Soceanu, A., Dobrinas, S., Popescu, V., Birghila, S., Magearu, V. (2007). Comparative study of some essential elements in different types of vegetables and fruits. Environ. Eng. Manag. J., 6 (6), 593-596.

Vincevica-Gaile, Z. (2014). Impact of environmental conditions on microand macroelement content in selected food from Latvia. Doctoral Thesis, University of Latvia, Riga, Latvia. 180 lpp. Available from: https://dspace.lu.lv/dspace/handle/7/4931

Vincevica-Gaile, Z., Klavins, M., Rudovica, V., Viksna, A. (2011). Trace and major elements in food articles in Latvia: Root vegetables. Sci. J. Riga Tech. U., Series: Environ. Climate Technol., 13 (7), 119-124.

Warming, M., Hansen, M. G., Holm, P. E., Magid, J., Thomas, H., Hansen, T. H., Trapp, S. (2015). Does intake of trace elements through urban gardening in Copenhagen pose a risk to human health? Environ. Pollut., 202, $17-23$.

Wunderlich, S., Feldman, C., Latif, K., Punamiya, P. (2011). Soil composition of community gardens: Are there quality concerns? In: Popov, V., Brebbia, C. A. (eds.). Food and Environment. WIT Press, Southampton, pp. 95-101.

Zariňš, Z., Neimane, L. (2009). Uztura mācība [Nutrition Studies]. (5 $5^{\text {th }}$ ed.), LU Akadēmiskais apgāds, Rīga. 464 lpp. (in Latvian).

Received 5 October 2016

Accepted in the final form 11 October 2017

\section{POTENCIĀLI TOKSISKO ELEMENTU NOTEIKŠANA NO RĪGAS PILSĒTAS MAZDĀRZIN̦IEM IEGŪTĀS OGĀS}

Pārtikas piesārnojums ir svarīgs pētījumu objekts, kas var kalpot par informācijas avotu kā nozares profesionāḷiem, tā patērētājiem. Pētījuma mērḳis bija ievākt un analizēt dažādu ogu paraugus — jāṇogas, upenes, ērkšḳogas, avenes, zemenes un kiršus, kas audzēti mazdārziņos Rīgas pilsētā. Paraugi tika izžāvēti, sasmalcināti un mineralizēti, karsējot koncentrētā $\mathrm{HNO}_{3} / \mathrm{H}_{2} \mathrm{O}_{2}$ šḳīdumā. Izmantojot atomabsorbcijas spektrometriju, paraugu škīdumos tika noteikta potenciāli toksisko elementu kvantitatīvā koncentrācija, kas, ṇemot vērā vidējo koncentrāciju, l̦āva sarindot elementus ogās šādā secībā: $\mathrm{Fe} \mathrm{Zn} \mathrm{Cu} \mathrm{Ni} \mathrm{Pb} \mathrm{Cr} \mathrm{Cd}$. Toksikoloǵgiski svarīgākie potenciāli toksiskie elementi ogās kopumā tika konstatēti vidēji Ni $0,54 \mathrm{mg} / \mathrm{kg}, \mathrm{Pb} 0,20 \mathrm{mg} / \mathrm{kg}, \mathrm{Cr} 0,10 \mathrm{mg} / \mathrm{kg}, \mathrm{Cd}$ 0,03 mg/kg, taču elementu koncentrācijas sadalījums katrai ogu sugai bija atškirīgs, kas neizslēdz iespējamo piesārṇojuma radīto risku patērētājam. 